\title{
СУЧАСНІ ПІДХОДИ ДО ВИКЛАДАННЯ ОКРЕМИХ ПИТАНЬ АКУШЕРСТВА ТА ГІНЕКОЛОГІї
}

\author{
Л. М. Маланчук, 3. М. Кучма, І. М. Маланчин, О. А. Франчук, Л. С. Лимар, \\ Л. І. Романчук, В. М. Флехнер
} ДВНЗ “Тернопільський держсавний медичний університет імені І. Я. Горбачевського МОЗ Украӥни”

\section{MODERN APPROACHES TO TEACHIHG SOME QUESTIONS OF OBSTETRICS AND GYNAECOLOGY}

\author{
L. M. Malanchuk, Z. M. Kuchma, I. M. Malanchyn, O. A. Franchuk, L. Ye. Lymar, \\ L. I. Romanchuk, V. M. Flehner \\ SHEI "Ternopil State Medical University by I. Ya. Horbachevsky of MPH of Ukraine"
}

\begin{abstract}
Сьогодні дуже актуальні питання юридичного забезпечення медичної діяльності. Потреби медичної практики зумовлюють доцільність вивчення деяких юридично-правових норм, основ законодавства України про охорону здоров'я.
\end{abstract}

In our days the issue of juridical support of medical practice is very actual. Requirements of medical practice need studying of some juridical standards and base of Ukrainian legislation on health protection.

Вступ. Життя та здоров’я людини перебувають під захистом не тільки моральних норм, але й норм законодавства, зокрема Конституції, Цивільного та Кримінального кодексів України. Саме медицина у людей сприймається подвійно: як засіб допомогти людині, і як потенційно агресивний чинник, що може обтяжувати стан здоров'я людини або навіть викликати захворювання. Суспільні відносини, що виникають у сфері медичної діяльності, регулюються не тільки нормами медичного права. Багато відносин між пацієнтами і представниками медичних установ знаходяться під значним впливом етичних і моральних норм і не можуть бути регламентовані законом. В деяких галузях медицини, зокрема в акушерстві та гінекології, це набуває особливого значення.

Основна частина. Викладання предмета "Акушерство та гінекологія" має ті особливості, що доводиться щодня стикатися 3 дуже делікатними, часто інтимними питаннями, нерідко їх вирішення знаходиться в правовій площині. Разом з тим, досвід показує, що студенти VI курсу, які закінчують навчання, а тим більше IV-V курсів, не ознайомлені з елементарними основами законодавства, що стосується охорони репродуктивного здоров'я жінки, перинатальної охорони тощо.

Більшість медиків не сумнівається в тому, що не лише вагітна жінка, а і її плід має право на допомогу, що зачата дитина може бути пацієнтом і саме так

\footnotetext{
(c) Л. М. Маланчук, 3. М. Кучма, І. М. Маланчин та ін.
}

має трактуватися плід при наданні допомоги in utero, яка набуває все більш широкого застосування. Міжнародна конвенція про права дитини вже в преамбулі передбачає особливу турботу й допомогу, а також відповідний правовий захист дитини ще до ії народження. У частині 1 ст. 24 Конвенції визначено, що країни-учасниці визнають право дитини на якомога кращий стан здоров'я. Окрім того, в ч. 2 йдеться про реалізацію цього права, зокрема, шляхом забезпечення матері відповідної пренатальної та постнатальної допомоги.

В світлі рішень Постанови Кабінету Міністрів України № 1849 від 27.12.06 Державної програми "Репродуктивне здоров' я нації на період до 2015 року”, в Україні останніми роками запрацював національний проект "Нове життя - нова якість охорони материнства та дитинства". Для реалізації даної концепції видано ряд наказів MO3 України, спрямованих на покращення перинатальної допомоги (наказ № 539 від 04.03.2006 "Про організацію діяльності служби планування сім'ї та охорони репродуктивного здоров’я в Україні”; наказ № 204 від 13.04.2011 “Про затвердження та впровадження примірного переліку послуг перинатальної допомоги на всіх етапах іiі надання"). Сучасна медицина розвивається надзвичайно швидко, і цей розвиток привів до виокремлення нової спеціалізованої галузі медицини перинатології, яка, по суті, є медициною матері і плода. В літера- 
турі все частіше вживається це поняття (“медицина матері і плода”) для підкреслення факту, що однаковою увагою має бути оточена і мати, і плід. При викладанні модуля “Фізіологічний перебіг вагітності, пологів та післяпологового періоду” на цьому слід акцентувати особливу увагу. При вивченні патологічного акушерства важливо підкреслювати, що різноманітні медичні процедури за участю плода, які проводяться з метою запобігання, виявлення та усунення патологічних станів, проводяться в організмі матері і впливають на нього.

Пренатальна діагностика охоплює ряд методів і процедур, що проводяться в період до народження дитини, метою яких є своєчасне виявлення аномалії розвитку плода та виокремлення групи жінок підвищеного ризику.

Є досить багато неінвазивних методів дослідження у пренатальному періоді, які не порушують стану плода при обстеженні жінки з групи підвищеного ризику. Найбільш поширеним є візуально-діагностичне УЗД. Це дослідження досить інформативне, щодо вад розвитку, але не дає відповіді на питання, чи здорова дитина. Визначення рівня гормонів, ферментів дозволяє оцінити стан метаболізму плода. Аналіз біохімічних показників (рівень естріолу, $\beta$-субодиниць ХГ, альфа-фетопротеїну, А-білка плазми крові РАРРА), можливість прогнозувати перебіг вагітності, оцінити розвиток плода, включаючи діагностику вад розвитку (наказ МО3 України № 417 від 15.07.2011 "Про організацію амбулаторної акушерсько-гінекологічної допомоги в Україні”). Перелік і показання до цих досліджень повинні знати всі сімейні лікарі. Що стосується інвазивних досліджень, то вони нерідко є предметом гострої критики і дискусії, оскільки це пов'язано із значним ризиком викидня через порушення цілісності тканин плода - це і амніоцентез, i біопсія трофобласта, кордоцентез тощо. Медична література доводить їх достовірність, це дає більшу ймовірність встановлення діагнозу, ніж при використанні неінвазивних методів. Для використання цих методів важливо опрацювати критерії відбору жінок, що регламентовано наказом МОЗ України № 641/84 від 31.12.2003 р. "Про удосконалення медико-генетичної допомоги в Україні”.

Важливим $є$ вирішення питання про переривання вагітності за медичними показаннями (наказ МO3 України №1177 від 31.12.2010 "Про затвердження клінічного протоколу “Комплексна допомога під час небажаної вагітності”). Тут мати є “суб’ єктом” процедур, а також приймає рішення щодо продовження життя дитини. Питання дуже делікатне і вимагає такого ж підходу у розмові з жінкою та їі сім'єю.

Як бачимо, виникає багато соціально-правових питань лише у сфері перинатології. Більшість з них регламентовано відповідними наказами МОЗ України. Для реалізації цих питань у практиці сімейного лікаря, на наш погляд, необхідно не лише ознайомлення 3 цими документами, а й ретельне їх вивчення. Недоцільно виносити це на самостійне опрацювання, це вимагає не лише вивчення, але й тлумачення та усвідомлення доцільності.

Разом 3 тим, деякі питання навчальної програми навряд чи доцільно вивчати майбутнім сімейним лікарям, оскільки це не передбачено "Галузевими стандартами” вищої медичної освіти (наприклад “Акушерські щипці” чи “Акушерські повороти”). Знання цих тем має бути в межах, що дозволить визначити групу ризику, в якій можливе виникнення необхідності виконання цих операцій, щоб своєчасно госпіталізувати таких жінок. Разом $з$ тим, на вивчення питань планування сім’і програмою відведено лише 2 год на 5 курсі (разом із темою “Неплідний шлюб” - 4 год).

Отже, вважаємо за доцільне в робочу програму внести питання “Основи законодавства” і не лише 3 проблем, які наведені вище, а зі всіх, з якими може зустрітись сімейний лікар чи лікар загальної практики. Трапляється, що випускники не знають елементарних юридичних норм щодо повідомлення про проведену операцію (родичам, чоловікові), юридичних норм при проведенні ЕКЗ тощо. Слід оволодіти не лише наказами MO3 України, але і законодавчими актами, що виходять із “Основ законодавства України про охорону здоров'я”.

Сама суть Свропейської конвенції полягає у повазі гідності й свободи людини, а поняття самовизначення та особистої автономії є важливими принципами, що лежать в основі тлумачення гарантій їх дотримання. Студенти повинні знати, що навіть у тих випадках, коли відмова від конкретного методу лікування може призвести до летального наслідку, примусове лікування без згоди дієздатного повнолітнього пацієнта є втручання у його право на особисту недоторканість і посягання на права, гарантовані ст. 8 Європейської конвенції.

У вітчизняному законодавстві міститься обмеження можливостей людини на реалізацію права на відмову від медичного втручання за певних умов, зокрема: невідкладності випадку, реальної загрози життю пацієнта (ч. 5 ст. 284 ЦК України та ч. 2 ст. 43 Основ законодавства України про охорону здоров’я). Звичайно, виникає необхідність удосконалювати знання викладачів 3 питань нормативно-правової бази не лише 
шляхом самоосвіти, а було б доцільно вводити їх в програми курсів педагогічного вдосконалення.

Сьогодні назріло питання трактування терміна “якість медичного обслуговування”. Серед численних визначень найвдалішим є таке: якість медичного обслуговування - це сукупність тих властивостей медичних втручань, що характеризують їх здатність задовольняти потреби пацієнтів у поліпшенні (підтримці) оптимального стану здоров' я.

Наказом MO3 України закріплено 13 показників (критеріїв) якості надання медичної допомоги, зокрема: доступність медичної допомоги; іiі економічність, ефективність, наступність, науково-технічний рівень, рівень дотримання технологічності, рівень якості диспансеризації, рівень якості діагностики; рівень якості лікування, рівень якості обстеження, рівень якості профілактики, рівень якості реабілі-

\section{Література}

1. Думалевська М. Правова оцінка медичних процедур, що застосовуються під час вагітності / М. Думалевська // Право України. - 2011. - № 11-12. - С. 91-102.

2. Законодавство України про охорону здоров'я / під ред. В. Ф. Москаленка // Бюлетень законодавства і юридичної практики України. - 2000. - № 7. тації, ступінь задоволеності пацієнтів отриманою медичною допомогою.

Найкраща модель медичного обслуговування відображається у послідовності взаємопов'язаних етапів: профілактика - діагностика - лікування - peабілітація.

Майбутні фахівці зобов' язані знати про необхідність проведення окремих видів медичних втручань (наприклад, штучне переривання вагітності, застосування допоміжних репродуктивних технологій) лише в акредитованих закладах охорони здоров’я.

Висновок. Таким чином, реорганізаційні зміни в медичній сфері, майбутнє впровадження страхової медицини, будуть вимагати від медиків знання юридичних аспектів послуг в охороні здоров'я. Тому розгляд цих питань слід внести в навчальну програму 3 врахуванням тематики занять.

3. Збірник нормативно-директивних документів 3 охорони здоров'я (МОЗ України). -К., 2002.

4. Складові галузевих стандартів вищої освіти. Міністерство освіти і науки України. - К., 2002.

5. Стеценко С. Медичне право України / С. Стеценко // Право України. - 2011. - № 11-12. - С. 120-131. 